\title{
An International Comparison of Official Educational Research Institutes: Research Roles and Types
}

\author{
Bo-Ruey Huang ${ }^{\mathrm{a}, *}$ \\ ${ }^{a}$ Chinese Culture University, Taiwan
}

\begin{abstract}
In this paper, the research roles, research types, and effectiveness evaluations of official educational research institutes were investigated to understand the positioning of official educational research institutes in the academic community by employing documentary analysis and comparative method. Official education research institutes established with government resources conduct educational research with roles that emphasize the investigation and resolving of various educational problems in response to social change in the academic community. The types of research conducted by of ficial education research institutes indicate specific bases for action in education policy, provide solutions to educational problems, or compile and disseminate information on education throughout their countries by conducting applied research. Assessments of the effectiveness of the research conducted by official educational research institutes should be considered rigorous, relevant, and utility.
\end{abstract}

\begin{abstract}
Abstrak
Studi ini mengkaji peran penelitian, jenis penelitian dan keefektifan evaluasi oleh lembaga resmi riset kependidikan, guna memahami posisi lembaga riset di komunitas akademik. Kajian ini menggunakan metode komparasi dan analisis dokumen. Lembaga resmi riset kependidikan yang didirikan dengan fasilitas pemerintah cenderung menekankan penelitiannya pada investigasi dan penyelesaian masalah pendidikan terkait dengan perubahan sosial di komunitas akademik. Jenis penelitian oleh lembaga resmi riset kependidikan mengarah pada langkah-langkah spesifik kebijakan, solusi masalah, atau mengumpulkan dan mendiseminasi informasi pendidikan dari seluruh penjuru negeri melalui penelitian terapan. Keefektifian penelitian yang dilakukan lembaga resmi riset kependidikan dinilai menyeluruh, relevan dan bermanfaat.
\end{abstract}

Keywords: Research Institute, Comparative Research, Research Roles, Research Types, Educational Research

\footnotetext{
*Corresponding author. Address: Chinese Culture University, Taiwan. Email: hbr2172@gmail.com.
}

\section{Introduction}

Research institutes hold an indispensable status in academic activities. They are the sites at which academic research is conducted, knowledge is developed and applied, and solutions to problems are found. All academic fields have their particular research institutions covering areas such as politics, economics, education, sociology, outer space, geography, oceanology, and biology. If divided according to their affiliations, research institutes can be categorized into university-affiliated research institutes, non-official or private research institutes, and official research institutes. University-affiliated research institutes are the most common, generally because the research environment in which they are located has specified research objectives. Non-official or private research institutes are relatively close to industry. They are assigned specific directions for research depending on their sources of funding; examples include 
the Research and Development Corporation and the Carnegie Corporation of New York. Official research institutes are funded by countries or governments for certain purposes; therefore, the research roles and types of these institutes differs from that of general academic research institutes. In the academic system, these research institutes, with varying properties, differ in the research roles they play, types of research they conduct, and methods by which they evaluate research.

Depending on the subject areas or research tasks of official research institutes, they are assigned specific institutional goals or research roles. In the field of education, advanced countries worldwide have established official educational research institutes to focus on educational issues, improve educational quality, identify development trends in education, provide education information, investigate key topics in education, and establish foundations to respond to changes. Examples of official educational research institutes include the Institute of Education Sciences (IES) in the United States, the German Institute for International Educational Research (Deutsches Institut für Internationale Pädagogische Forschung, DIPF) in Germany, and the National Institute for Educational Policy Research (NIER) in Japan. In addition, international organizations, such as the European Union (EU), have established affiliated official educational research institutes. These official educational research institutes are assigned specific functions and tasks to conduct key educational research and related activities.

Key aspects for understanding official educational research institutes include how the functions and tasks of these institutes differ from those of general research institutes, whether their research activities and types are special, and how the effectiveness of the research conducted by these institutes should be evaluated. In this study, the research roles, research types, and effectiveness evaluations of official educational research institutes were investigated to understand their positioning in the academic community as well as the relationship between official educational research institutes and educational practices.

The remainder of this paper is organized as follows: Section 2 discusses the functions and research roles of official educational research institutes in the academic community, Section 3 presents an analysis of the special research types and tasks of official educational research institutes based on their research roles, and Section 4 details the standards used to assess the effectiveness of research in official educational research institutes based on their research types. Finally, Section 5 concludes this paper.

\section{Research Roles of Official Educational Research Institutes}

At their inception, official educational research institutes have compelling reasons and bases to convince the community to accept the use of the government in their establishment. For example, when the U.S. Congress passed the Education Sciences Reform Act (ESRA) and created the Institute of Education Sciences (IES) in 2002, various sectors questioned whether the IES would repeat the mistakes of the dysfunctional National Institute of Education and the Office of Educational Research and Improvement. However, the National Research Council and relevant literature report that the IES was established when educational research that could provide foundations and evidence to be followed or used for educational problem-solving and policy was necessary. Conducting practical research to meet this need has been a critical principle for the IES since its founding, enabling it to function as an official educational research institute (National Board for Education Sciences [NBES] 2008, 2010).

The functions of official educational research institutes are positioned as a whole in the context of the division of academic responsibilities between public and private research institutes. This positioning is used to determine the roles played by these institutes in the academic community. For example, to establish globally competitive research and innovation, the EU launched investigations of public and private research centers as well as research and technology organizations within its borders. The scope of these investigations encompassed the organizational status, functions, roles, allocation of government or private funds, funding models, research types, application and promotion of results, operating models, and research capabilities and potential of public and private research institutes. Simultaneously, these investigations attempted to determine the professional activities and research types of research institutes, enabling them to adjust their research policies and cooperation strategies within the borders of the EU. The investigations revealed that the official research institutes of nations and international organizations differed in their missions. In addition, the functions of the research institutes led to differences in research activities and roles (Policy Research in Engineering, Science, and Technology 2002; European Research Advisory Board [EURAB] 2005). Table 1 shows the results.

The table shows that the functions of a research institute determine the content of its activities and the role it plays in the academic community. The functions, roles, and activities of research institutes are closely connected. Furthermore, activities and research types are used as an evidence base to assess the reason for an institute's existence.

For example, if an institute's function is to conduct fundamental research, its activities would be strategically critical fundamental 
research or long-term research in its professional field. The role that the institute plays may connect broadly with interdisciplinary research of varying depth and breadth. Thus, the necessity of the institute's existence is in its role as an integrator between industry and academia in a certain field. By contrast, if an institute's function is to support public policy decisions or implementation, its activities would be directed toward evaluation, investigation, or supervision. The institution plays an impartial role and the reason for the institute's existence is in its ability to bear social responsibility for the risk of administration in its field. If an institute's function is in technological development and support, its research would focus more on research activities that extend technologies, industry services, and cooperative research activities. The role the institution plays would be closer to the market or society.

Table 1. The Functions, Activities, and Roles of European Research Institutes

\begin{tabular}{|l|l|l|}
\hline Functions & \multicolumn{1}{|c|}{ Activities } & \multicolumn{1}{c|}{ Roles } \\
\hline $\begin{array}{l}\text { Fundamental } \\
\text { Research }\end{array}$ & $\begin{array}{l}\text { Long-term or longitudinal } \\
\text { research activities; strategi- } \\
\text { cally critical research activ- } \\
\text { ities }\end{array}$ & $\begin{array}{l}\text { Has the relevance to facili- } \\
\text { tate a comprehensive and } \\
\text { broad interdisciplinary inte- } \\
\text { gration between industry } \\
\text { and universities in a certain } \\
\text { field. } \\
\text { Must integrate basic and ap- } \\
\text { plied research to ensure } \\
\text { knowledge integration. For } \\
\text { example, integrating } \\
\text { knowledge with external re- } \\
\text { sources. }\end{array}$ \\
\hline $\begin{array}{l}\text { Supporting } \\
\text { Public Policy }\end{array}$ & $\begin{array}{l}\text { Preventive research activi- } \\
\text { ties; public risk assessment } \\
\text { and monitoring }\end{array}$ & $\begin{array}{l}\text { Is fair and unbiased; is pub- } \\
\text { licly responsible and ac- } \\
\text { countable }\end{array}$ \\
\hline $\begin{array}{l}\text { Technologial } \\
\text { Development } \\
\text { and Support }\end{array}$ & $\begin{array}{l}\text { Research activities aimed at } \\
\text { extending technologies; in- } \\
\text { dustry-university service } \\
\text { and cooperative research } \\
\text { activities }\end{array}$ & $\begin{array}{l}\text { Fills gaps in the market; ac- } \\
\text { celerates the promotion and } \\
\text { dissemination of technology }\end{array}$ \\
\hline $\begin{array}{l}\text { Technical } \\
\text { Specifications } \\
\text { and Standards }\end{array}$ & $\begin{array}{l}\text { Supervision and chartering } \\
\text { Source: Europ }\end{array}$ & $\begin{array}{l}\text { Is independent and can im- } \\
\text { plement arbitration and } \\
\text { monitor security. }\end{array}$ \\
\hline
\end{tabular}

Source: European Research Advisory Board (2005, pp. 7-8).

The activities of research institutes determined in the aforementioned investigations comprised fundamental research, applied research, development, certification and standards, diffusion and extension, and the provision of facilities. Applied research was the most common of these activities and accounted for $92 \%$ of research institute operation; and development and fundamental research accounted for $80 \%$ and $50 \%$ of research institute operation. The following table presents the primary activities of the research institutes.
Table 2. Activities and of the Research Institutes

\begin{tabular}{|l|c|}
\hline Activity & Percentage \\
\hline Fundamental Research & $52 \%$ \\
\hline Applied Research & $92 \%$ \\
\hline Development & $80 \%$ \\
\hline Certification and Standards & $32 \%$ \\
\hline Diffusion and Extension & $67 \%$ \\
\hline Provision of Facilities & $33 \%$ \\
\hline
\end{tabular}

Source: European Research Advisory Board (2005, p. 15).

Activities that research institutes engage in can be further used to divide their research into different types. The aforementioned investigations have indicated that research institutes engage in both fundamental and applied research simultaneously. Fundamental research seeks to understand phenomena as an approach to developing knowledge; applied research may be short-term (contract research to be applied immediately) or long-term (long-term strategic research to develop technologies). Objectives of applied research and their characteristics are reflected in the management challenges encountered by the institutes, such as balancing the allocation of funds for long- and short-term research or finding a compromise between public resources and injections of other resources. In addition, different research institutes should be conscious of the roles they play, what differentiates them from others, and their contributions to the research community as a whole. Institutes should be able to display their key functions in the overall academic system and exhibit different characteristics and advantages.

The functions of a research institute are closely related to the activities in which it engages and the roles it plays. This relationship can be used to further observe the research functions and roles of official educational research institutes. According to the ESRA, the function of the U.S. IES is to conduct the following activities either directly or through grants, contracts, or cooperation: (1) execute and sponsor scientific research activities, including basic and applied research, statistics, and science-based educational evaluation, development, and promotion; (2) widely promote science-based educational research findings and results; (3) promote the use, development, and application of knowledge derived from science-based research activities; (4) strengthen the capability of science-based educational research to be implemented, developed, and disseminated widely throughout the country; (5) promote the coordination, development, and dissemination of science-based educational research within the federal government and the Department of Education; and (6) promote the use and application of research and development to improve actual classroom situations.

Although the first of these six items mentions that the research activities conducted and sponsored by institutes include basic and applied research, the other items emphasize the further promotion, 
use, development, application, and dissemination of research results.

The functions of official educational research institutes in other countries have been described in a similar fashion. The main activities of the German DIPF are based on the complementary fields of educational information and educational research. In the dimension of educational information, the DIPF establishes databases and information systems to provide core infrastructure for educational information in Germany. All of these services can be accessed on the Internet or at libraries. In the dimension of educational research, the DIPF emphasizes different levels of research on education systems, institutes, and individuals as well as critical reflection on key concepts in quality, management, and development. In addition to its research role, the French Institute of Education (Institut Françaisde l'Éducation IFÉ) provides extensive facilities and services. The facilities of the IFÉ include libraries, the National Museum of Education, and publishing houses. The services of the institute are intended to provide "Training" and "Scientific Watch". Japan's NIER focuses on educational administration and policy issues. The NIER conducts basic research on the planning of educational policies and cooperates with other institutes for research projects on key educational topics.

The official research institutes of the EU directly address education-themed research activities at the EU level or similar activities relevant to each country. These activities include (1) providing information required for decision-making and public debates, (2) acting for the decision-makers in each country or region, (3) observing the education systems of member states, (4) developing special knowledge based on academic principles, (5) adopting diverse methods to conduct educational research, (6) providing a variety of publications on education in Europe, and (7) collaborating with partners.

A comparison of the relationships between the research functions, activities, and roles listed in Table 1 revealed that the functions of official educational research institutes appear to emphasize applied research as opposed to basic or fundamental research. However, prior to making this assertion, one must understand the differences between the terms used by EU states and those by other countries of the world (i.e., fundamental research and applied research vs. basic research and applied research); in other words, in EU investigations, the functions of research institutes were divided into fundamental research and applied research. By contrast, the official educational research institutes of numerous other countries identify these as basic research and applied research. In current academic research and communities, the opportunity for pure basic research is close to minimal.

Stock (1997) analyzed basic research and indicated that this concept originated in ancient Greece. German idealist philosophers claimed that basic research is the pursuit of pure knowledge without any practical purpose. Traditionally, the pursuit of knowledge was an activity of the upper classes or traditional elite and lacked material motivations and therefore required no external sources of funding. To the upper classes, the pursuit of knowledge was merely a leisure activity. This activity began to become connected with society when promoted by multiple scientific research organizations in Europe. Nevertheless, the scientists in these organizations still belonged to the traditional elite classes (Reingold 1991, pp. 56-57). In the nineteenth century, the scientific community began to accept the concepts of pure research versus applied research. However, following industrialization and the development of engineering research, the opportunity for pure research continued to decrease. Thus, the concept of basic research appeared and replaced pure research (Kline 1995, p. 197).

During World War II, academic research began to be conducted for national military purposes, and public grants gradually became a key source of funding for the scientific community. Society began to depend on the results of scientific research, and the scientific community began to take government subsidies for granted (Elzinga and Jamison 1995, pp. 578-580). During the Cold War, the Sputnik crisis led to massive funding for scientific research. The use of public finance to subsidize basic research gradually became rationalization and legitimate. In the 1980 s, the pressures of international competition began to affect countries worldwide. Basic research was closely linked to technological development and production in society, but simultaneously, scientists were gradually forced to prove that their research would provide potential benefits for society and the economy. Thus, basic research had evolved to become oriented toward applications. As basic research began to receive grants from the government, which sought its social value, it shifted from "scientific research in pursuit of pure knowledge and truth" to "scientific work toward social and economic objectives" (Slaughter 1993, p. 288).

\section{Types of Research Conducted at Official Educational Re- search Institutes}

The previous section states that basic research has turned toward applied research in current research fields. This section addresses the types of research conducted by official educational research institutes and whether these institutes should conduct basic research, fundamental research, or applied research.

The context of the research tasks conducted by official educational research institutes can be traced back to UK traditions. The second section indicates that, traditionally, before education policies were implemented in the United Kingdom, the central educa- 
tion advisory council or specially appointed committees would conduct investigations and prepare reports. The central authority of education would then implement policies where appropriate on the basis of the recommendations in the reports. This tradition indicates that educational research commissioned by a country essentially meets the needs of the country or society as a whole. Thus, educational research supported and sponsored by a country primarily addresses the educational conditions that the nation and society seek to understand or the educational problems they wish to resolve.

Whitehurst (2003), the first director of the U.S. IES, stated that the mission of the IES is to provide information on educational programs for decision-makers in education and the federal government. In other words, the IES's "customers" are practitioners in education, education policymakers, and the general public. The characteristics of this task indicate that the educational research that the IES must conduct is neither fundamental knowledge nor basic research, as these are the tasks to be completed by the National Science Foundation (NSF), an organization that aims "to promote the progress of science"; the mission of the IES, by contrast, is to conduct applied research that provides specific actions, solutions to practical problems in education, and useful information for the public.

As shown in Table 3, Whitehurst (2003) used the concepts detailed in Pasteur's Quadrant (written by Stokes 1997) to distinguish three types of research (i.e., pure basic research, use-inspired basic research, and pure applied research) on two dimensions. The first dimension is consideration of use, which is divided into high or low. The second dimension is a quest for fundamental understanding, which is divided into present or absent.

Table 3. Types of Research

\begin{tabular}{|l|c|c|c|}
\hline \multicolumn{2}{|c|}{} & \multicolumn{2}{c|}{ Consideration of Use } \\
\cline { 3 - 4 } \multicolumn{2}{|c|}{} & Low & High \\
\hline $\begin{array}{l}\text { Quest for Funda- } \\
\text { mental Understand- } \\
\text { ing }\end{array}$ & Yes & $\begin{array}{c}\text { Pure Basic Re- } \\
\text { search }\end{array}$ & $\begin{array}{c}\text { Use-Inspired Basic } \\
\text { Research }\end{array}$ \\
\cline { 2 - 4 } & No & $\begin{array}{c}\text { Pure Applied Re- } \\
\text { search }\end{array}$ \\
\hline
\end{tabular}

Source: Extracted by the author from Whitehurst (2003, p. 3).

"Pure basic research" is conducted by theoretical physicists such as Niels Bohr, who pursue basic knowledge and pay little attention to application. "Pure applied research" is conducted by researchers such as Thomas Edison, who aim to solve problems. These researchers adjust their work to solve problems as quickly and effectively as possible, regardless of whether basic knowledge or technical knowledge is required. "Basic research inspired by applications" is similar to the bacteriology studied by Louis Pasteur, who was commissioned by the wine industry. This type of research seeks fundamental knowledge about potential problems in the real world.
Whitehurst (2003) argued that the type of educational research that the IES must conduct belongs in the fourth quadrant, in which consideration of use is high and the quest for fundamental understanding is unnecessary. In other words, the IES should conduct pure applied research. Using a vivid metaphor, Whitehurst stated,

Education is ... a field in which there is a gulf between the bench and the trench, and in which the trench is complicated by many players, settings, and circumstances. Choose what you consider to be the most exciting developments in Bohrs' or Pasteur's quadrants that are relevant to education ... ask yourself what would need to be done to translate those imagined findings into applications that would have wide and powerful effects on education outcomes... I'm not optimistic that the results of basic research, even if the findings are powerful, will flow directly and naturally into education.... The model that Edison provides of an invention factory that moves from inspiration through lab research to trials of effectiveness to promotion and finally to distribution and product support is particularly applicable to education. In summary, the Institute's statutory mission ... points the Institute toward applied research, Edison's quadrant." (Whitehurst 2003, p. 4)

This explanation indicates that the statutory mandates of official educational research institutes are generally positioned toward providing bases for action on particular educational strategies, solutions to problems, and educational information to be disseminated nationwide. Research purposes and methods are extended from these types of statutory mandate and differ completely from those of general academic research. The type of research conducted by official educational research institutes is more closely connected to practicality and topics from the real world, and these institutes expend relatively little effort pursuing basic knowledge and understanding in the field of education. The methods required to research actual topics in education must be consistent with actual needs. Solutions or strategies for problems must be provided, not theories.

"Use-inspired basic research" should be classified as "fundamental research." In education, fundamental research refers to "providing fundamental knowledge to improve learning or education outcomes. This type of research focuses on testing, developing, and correcting teaching or learning theories and may be used to develop new teaching methods or techniques, influencing the development of education in a variety of contexts" (IES 2013, p. 9). Fundamental research differs from basic research, which pursues pure knowledge, but is not entirely the same as applied research, which merely seeks solutions to certain problems. Fundamental research acts as an integrator between fundamental knowledge and problem applications in research institutes and may be used to develop and 
correct theoretical knowledge based on practical circumstances.

The German Federal Ministry of Education and Research (Bundesministerium für Bildung und Forschung, BMBF) emphasizes the points and development directions on which educational research should focus on. The BMBF's framework program to promote empirical educational research reexamines the role of educational research in the twenty-first century. The program indicates that educational research is a critical foundation for promoting international competitiveness and ensuring the quality and development of education in Germany. Educational research plays a crucial role in conducting preventive research, long-term policy, research on international contexts, and shaping influential political content. The relationship between educational research and the reality of education has long been an input-based control mechanism. This orientation has slowed and lost its effectiveness because of the current rapidly changing knowledge society. In addition, this orientation cannot provide a foundation for decision-making in education. In a postindustrial society based on knowledge, education plays a key role in international competition. Therefore, educational research must be oriented toward output with evidence-based control models. This includes becoming oriented toward predictable output that can assist organizations in the process of gathering information and feedback. The collected information is connected to output and is ultimately reflected in input, performance, and achievement. The following must be pursued to achieve this process in the field of education (Bundesministerium für Bildung und Forschung 2008):

1. Scientific methods must be used to investigate and form conclusions regarding effective mechanisms for teaching and learning processes.

2. Research must analyze both national (educational achievement) and international (educational achievement) performance.

3. Practical and synchronized periodic assessments and feedback (including internal and external assessments) must be developed. These methods must be capable of focusing on different institutional levels and triggering new reform measures.

4. High-quality systems for educational statistics must be developed.

Thus, the educational tasks of officially supported educational research primarily address the educational circumstances that the country and society seek to understand or the educational problems they wish to solve. Applied research is emphasized. Therefore, the statutory mandates of official educational research institutes place applied research at their core and extend this to related tasks such as maintaining data and promoting applied research results.
The mission published by the U.S. IES is to provide fundamental knowledge on education for the general public and to provide reliable information in the following areas: (1) the status and progress of education in the United States, including early childhood education; (2) actual circumstances of education with regard to supporting students' learning, improving subject achievement, and providing access to educational opportunities; and (3) effectiveness of the federal government and various educational programs. In addition to these tasks, the institute should compile statistics, develop results, conduct research and evaluation, and disseminate reports on the actual needs of regions throughout the country. The federal government provides funding for these activities to ensure that all of them can be achieved with high quality and standards. The institute should be impartial, neutral, non-ideological, nonreligious, and uninfluenced by political parties. In addition, the institute should have no ethnic, cultural, gender, or regional bias.

The German DIPF has argued for scientific infrastructure services and the evaluation of research and education systems as foundations to support educational research, practice, policy, and administration with the goal of improving education. As a member of the Leibniz Association, the DIPF conducts fundamental research by applying innovative developments and practices. This institute acts as a central interface for the integration of educational knowledge and promotes the improvement of the quality of education in all fields in Germany. The DIPF's tasks include (1) establishing educational knowledge and providing evidence bases for educational research design for action at all levels, (2) classifying and converting various types of educational knowledge for the use of different subjects and the general public, and (3) establishing archives and indicators for educational knowledge from a historical perspective.

The mission of the French IFÉ is to encourage and promote research in the various fields of education and training for experts and teams of education researchers, trainers, and decision-makers. However, the IFÉ does not claim to be able to cover the entire field of education and does not completely control educational research. This institute is dedicated to developing partnerships with other institutes and simultaneously seeks to meet the needs of the founders and researchers of schools and institutions of higher education. Therefore, the IFÉ has two main objectives: (1) encouraging and developing research in the field of education; and (2) maintaining, boosting, organizing, and promoting educational information.

The mission of the Japanese NIER involves applications in teaching and practice: (1) conducting scientific investigations, analysis, and forecasts on education from an international perspective, with the results provided for the future planning and design of midand long-range education policies in Japan; (2) conducting scientific research on current topics in education and analyzing the current situation and social background, with the results provided for 
the planning and design of educational policy in response to social needs; (3) providing the assistance, support, and recommendations required for social and school educational activities; (4) collecting, compiling, and storing educational information, data, and documents for the reference of Japanese and foreign interest groups; and (5) collecting educational knowledge and promotional information for Japanese and foreign educational research groups. In addition, the NIER conducts educational collaboration, seminars, and joint research.

\section{Effectiveness of Research Conducted by Official Educational Research Institutes}

The previous sections show that the research tasks of official educational research institutes primarily involve applied research, which focuses on research activities related to educational practice and problem-solving. According to this principle, assessments of the effectiveness of the research conducted by an official educational research institute, in addition to the research specifications that academic research must follow in general, should consider whether the institute has achieved the national objectives toward which its mission compels it or whether it has solved educational problems.

In the case of the United States, the ESRA that was passed in 2002 granted the IES greater independence compared with other research institutes in the past. In particular, although the IES remains a unit under the authority of the Department of Education, it is exempt from any political interference from the Department of Education and is excluded from numerous non-research functions. This exemption was achieved by assigning the IES an independent legal status. The director of the IES is nominated by the President instead of being appointed by the Secretary of Education and must be confirmed by Congress. The director's term is 6 years and is not limited by the President's term. What has mentioned above ascribes a critical legal status to the IES and exempt its director from the effects of political parties and politics.

However, this unique legal status means that the management of the IES follows an atypical pattern of administration. The IES is not an independent agency like the NSF. This institute is within the Department of Education but is expected to operate independently without being affected by federal departments at the Cabinet level. Therefore, as stipulated by the ESRA, the director of the IES must report to the President, Congress, and the Secretary of Education every two years (Institute of Education Sciences 2008). There are three indicators in the IES's annual report and report to Congress: rigor, relevance, and utilization (IES 2005; NBES 2008, 2010). These three indicators are used to evaluate the effectiveness of the
IES and can be further divided into multiple secondary indicators (Baldwin et al. 2008), as shown in Table 4.

Table 4. IES evaluation indicators

\begin{tabular}{|c|c|}
\hline \multirow{2}{*}{ Rigor } & $\begin{array}{l}\text { The quality and quantity of rigorous educational re- } \\
\text { search }\end{array}$ \\
\hline & $\begin{array}{l}\text { The degree to which educational research has reached } \\
\text { standards of rigor }\end{array}$ \\
\hline \multirow{3}{*}{ Relevance } & $\begin{array}{l}\text { Whether the research provided by the institute satisfies } \\
\text { all stakeholders }\end{array}$ \\
\hline & $\begin{array}{l}\text { Whether the research conducted is consistent with the } \\
\text { priority objectives set for the institute's research }\end{array}$ \\
\hline & $\begin{array}{l}\text { The degree of relevance and immediacy between cur- } \\
\text { rent educational topics and research findings and ob- } \\
\text { jectives }\end{array}$ \\
\hline \multirow{2}{*}{ Utilization } & $\begin{array}{l}\text { Whether the evidence base demanded for educational } \\
\text { decisions is satisfied }\end{array}$ \\
\hline & $\begin{array}{l}\text { Whether the relationship between educational policy } \\
\text { and practice has been promoted }\end{array}$ \\
\hline
\end{tabular}

Rigor, relevance, and utilization are closely interconnected. For example, rigor refers to the quality and quantity of rigorous research and the degree to which this research has reached standards of rigor. The first secondary indicator refers to whether the research is entirely as efficacious and effective as it should be, whereas the second refers to the institute's ability to conduct rigorous educational research, which is related to the number and quality of its researchers. The most critical aspect of these indicators is the requirement for institutes to conduct research that features scientifically rigorous methodology. This methodology includes conducting random sampling and addressing cause and effect. This emphasis on rigorous methodology is used to assess whether the outcomes of the educational research meet the standards for scientific research and can serve as a basis for assessing the effectiveness of the research's "utilization" in educational policy and practice. In other words, the IES's research results must provide reliable and useful evidence bases during the formulation of subsequent educational policies. Finally, the relevance of the research means that evaluations of the IES focus on consistency between the institute's research objectives and work. The research conducted by the IES must focus on in-time current key topics in education and must be able to effectively reduce turnaround time between the release of databases and the publication of relevant information (Baldwin et al. 2008).

The U.S. ESRA requires the director of the IES to solicit the opinions of the general public regarding its work before defining the institute's research directions and priority themes. To accomplish this, the IES publishes potential work content in national publications and collects the public's response before developing its work priorities. The institute then delivers its priorities to the NBES for approval. This method ensures that the IES's research themes 
and directions remain relevant to educational practice and meet the needs of education sites as well as the expectations of society. In addition, this model shifts the IES's research priorities and work from the "communication model" of the past to a "promotion model." The priorities in this model become the main objective of the institute and focal points for subsidized research (NBES 2008, 2010).

The EU's Education, Audiovisual, and Culture Executive Agency (EACEA), the unit with which Eurydice is affiliated, follows similar methods when planning research policies. The EACEA performs "customer" satisfaction surveys annually and then adjusts its institutional policies and formulates new objectives according to the results. For example, the EACEA's 2011 annual report indicated that the institute's organizational objectives in 2011 were four policies based on the 2010 satisfaction survey, namely adjusting the application and review processes for grant programs, improving the principles and requirements of program applications and results reports, supporting and developing various activities for EU targets, and supporting the European Commission with preparatory work for the next phase of its programs. In addition, the EACEA planned a three-step project lifecycle for project and program management (EACEA 2009, 2011).

Figure 1. Project Lifecycle

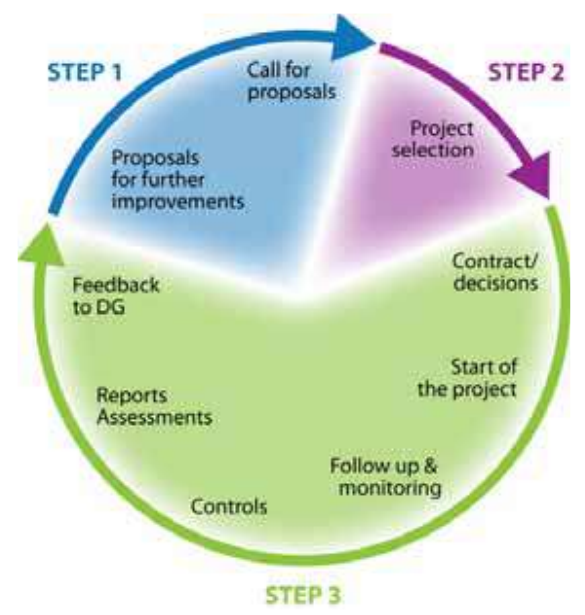

Source: EACEA (2011, p. 23). Reprinted with permission of EACEA.

The three-step project lifecycle begins with a call for project proposals. The second step is project evaluation and selection. The third step involves project execution, monitoring, control, and feedback. Finally, an evaluation report is produced and serves as a basis for the next project cycle. Overall project management is divided into three steps. The first step comprises the initial call for proposals and the final evaluation and planning. The second step comprises project evaluation and selection. The third step is project execution, monitoring, control, and feedback. This project lifecycle is EACEA's management model for project sponsorship. In addition to the four main activities in the steps of the project lifecycle, each step contains numerous secondary activities. However, the institute has found that the main challenges for project applicants are whether they understand the direction of projects sought, whether they understand the project application process, whether they have considered every detail, and whether the projects they propose are appropriate for the aims of the EU. Figure 1 shows this three-step project lifecycle.

Thus, the management mechanisms for research tasks, objectives, and effectiveness in EU research institutes and the US official educational research institute have shifted from the top-down communication model of the past to a bottom-up promotion model. $\mathrm{Nu}-$ merous European and US research institutes have coincided on using customer satisfaction surveys or opinion polls to gain feedback and adjust their research policies and priorities. In addition to the demand that specifications of rigor be followed in research methods, reviews of the research effectiveness of official educational research institutes should focus on the latest education topics. Their research results must serve as feasible evidence bases for formulating education policies or practicing at education sites.

\section{Conclusion}

Official educational research institutes are assigned specific functions and tasks; they are required to conduct key educational research and related activities. At the inception of official educational research institutes, the society should be convinced with compelling reasons and bases to accept government policy in establishing these institutes.

Educational research institutes established with national or government resources conduct educational research with functions, activities, and roles that emphasize the investigation and resolution of various educational problems in response to social changes in the academic community. The types of research conducted by official educational research institutes do not involve the pursuit of pure knowledge or theoretical construction to promote scientific progress. Rather, these institutes indicate specific bases for action in educational policy, provide solutions to educational problems, or compile and disseminate information on education throughout their countries by conducting applied research.

In addition to having strong reasons to establish and gain the trust of society, official educational research institutes must constantly provide evidence to prove and maintain their efficacy. The official educational research institutes of individual nations and international organizations use their statutory missions and evaluations of the effectiveness of their research as bases to display their 
efficacy. Assessments of the effectiveness of the research conducted by an official educational research institute, in addition to the research specifications that academic research must follow in general, should consider whether the institute has achieved the national objectives toward which its mission compels it or whether it has solved educational problems. Furthermore, in recent years, the management mechanisms for research effectiveness adopted by official educational research institutes have shifted gradually from a communication model to a promotion model. These institutes use external information and feedback to adjust their research policies and priorities, thus enabling the research they conduct to be rigorous, relevant, and useful.

\section{References}

Averch, Harvey A., Stephen J. Carroll, Theodore S. Donaldson, Herberl J. Kiesling, and John Pincus. 1972. How Effective is Schooling? A Critical Review and Synthesis of Research Findings. Santa Monica, CA: RAND Corporation.

Baldwin, Stephen E., Patricia A. Muller, Theresa M. Akey, John McManus, MacDonald Phillips, Jonathan Plucker, and Sean Sharp. 2008. An Evaluation of the Effectiveness of the Institute of Education Sciences in Carrying out its Priorities and Mission: Final Report. Institute of Education Sciences. Washington, DC: U.S. Department of Education.

Bundesministerium für Bildung und Forschung, 2008. Framework Programme for the Promotion of Educational Research. Berlin: Bundesministerium für Bildung und Forschung.

Education, Audiovisual and Culture Executive Agency. 2009. Interim Evaluation of the EACEA. Brussels: Education, Audiovisual and Culture Executive Agency.

Education, Audiovisual and Culture Executive Agency. 2011. 2011 Annual Activity Report. Brussels: European Commission.

Elzinga, Aant, and Andrew Jamison. 1995. "Changing Policy Agendas." In Handbook of Science and Technology Studies, edited by Sheila Jasanoff, Gerald E. Markle, James C. Petersen, and Trevor Pinch (pp. 572-597). Thousand Oaks, CA: Sage.

European Research Advisory Board. 2005. Research and Technology Organisations (RTOS) and ERA. Brussels: European Research Advisory Board Final Report.

Eurydice. 2013. Eurydice. Brussels: Education, Audiovisual and Culture Executive Agency. Available online at http://eacea.ec.europa.eu/education/eurydice/index_en.php; accessed 23 September 2013.

Institut National de Recherche Pédagogique. 2010. L'observatoire des thèses concernant l'éducation. Lyon, France : Institut National de Recherche Pédagogique. Available online at
http://www.INRP.fr/vst/Recherches/AccueilTheses.php; accessed on 23 December 2010.

Institute of Education Sciences (IES). 2005. Biennial Report to Congress. Washington, DC: U.S. Department of Education.

IES. 2008. Rigor and Relevance Redux: Director's Biennial Report to Congress. Washington, DC: U.S. Department of Education.

IES. 2013. Common Guidelines for Education Research and Development. Washington, DC: IES.

Kline, Ronald. 1995. "Constructing Technology as Applied Science: Public Rhetoric of Scientists and Engineers in the United States, 1880-1945," Isis 86 (June): 194-221.

Ministry of Education, Culture, Sports, Science and Technology (MEXT). 2013. About MEXT. Tokyo: MEXT. Available online at: http://www.mext.go.jp/english; accessed on 23 December 2013.

National Board for Education Sciences (NBES). 2008. National Board for Education Sciences: 5-Year Report, 2003 through 2008 (NBES 2009-6011). Washington, DC: NBES.

NBES. 2010. National Board for Education Sciences: 2010 Annual Report, July 2009 through June 2010 (NBES 2010-6004). Washington, DC: NBES.

National Research Council. 1999. Improving Student Learning: A Strategic Plan for Education Research and Its Utilization. Washington, DC: National Academies Press.

National Foundation for Education Research. 2011. Merger Creates New Force for Change in Education. Berkshire, UK : NFER.

National Institute for Educational Policy Research. 2013. NIER Research Introduction. Tokyo: National Institute for Educational Policy Research.

Policy Research in Engineering, Science, and Technology (PREST). 2002. A Comparative Analysis of Public, Semi-Public and Recently Privatised Research Centres. PREST Final Project Report (CBSTII contract ERBHPV2-CT-200-01). Brussels: Eurolab.

Reingold, Nathan. 1991. "American Indifference to Basic Research: A Reappraisal” In Science, American Style (pp. 5475). New Brunswick, NJ: Rutgers University Press.

Kline, Ronald. 1995. "Constructing Technology as Applied Science: Public Rhetoric of Scientists and Engineers in the United States, 1880-1945." Isis 86 (June): 194-221.

Slaughter, Sheila. 1993. "Beyond Basic Science: Research University Presidents' Narratives of Science Policy." Science, Technology, \& Human Values 18 (July): 278-302.

Stokes, Donald E. 1997. Pasteur's Quadrant: Basic Science and Technological Innovation. Washington, DC: Brookings Institution Press. 
Whitehurst, Grover. 2003. "The Institution of Education Science: New Wine, New Bottles.” Paper presented at the Annual Meeting of the American Educational Research Association, Chicago, IL, 21-25 April 2003. 